\title{
Spatial Analysis of the Availability of Health and Social Services for People with Special Needs
}

doi:10.2478/mape-2021-0040

Date of submission to the Editor: $05 / 2021$

Date of acceptance by the Editor: 06/2021

Patrycja Kabiesz

ORCID ID: 0000-0001-5920-7485

Silesian University of Technology, Poland

Joanna Bartnicka

ORCID ID: 0000-0003-1639-5804

Silesian University of Technology, Poland
MAPE 2021, volume 4, issue 1, pp. $442-452$

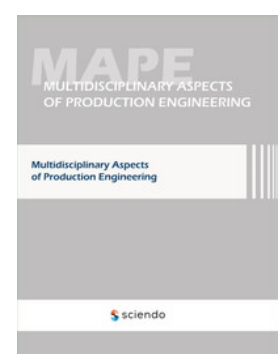

\section{INTRODUCTION}

A significant problem of the Polish health care system is the uneven distribution of resources that do not match the local needs of the population. This leads to a number of negative consequences, in particular the migration of people to urban areas to meet health needs (Marchetti et al., 2019). It is estimated that in 2050 , more than $65 \%$ of the world's population will live in urban areas (World Urbanization Prospects, 2014). The higher attractiveness and quality of life in cities and urban agglomerations is due to higher levels of productivity, guaranteeing cultural, social, and economic benefits to citizens. It is worth noting that the world population is increasing year by year, which means a huge number of urban residents in the future. Moreover, the changing population structure associated with increasing life expectancy and low fertility rates is a key demographic process (Levesque et al., 2013; Meyer et al., 2013). As a result, the growing number of older people will be one of the most important factors generating social change (Kaźmierczak et al., 2020), as this is a group with specific health problems (chronic diseases, multimorbidity, functional limitations and disabilities), which often leads to dependency and contributes to an increased demand for health and social services (Sowa, 2016). The challenge for future cities is to identify solutions that increase the sense of security, maintain functional capacity and health levels of people with special needs.

In Poland, care is most often provided in a traditional, informal way by family members (Golinowska, 2010) mainly by children (elderly parents live with their children) and "non-working women". However, due to lifestyle changes, work engagement (Sowa and Beaumont, 2015) and the increasing number of singlegeneration households (Derejczyk et al., 2016), there is a growing need for institutions that support the family in its caregiving functions (Błędowski et al., 2012). In contrast, the development of formalized, non-family care is in its early stages and concerns social and health care services that target the elderly, chronically ill, and disabled. Health care has mainly medical and rehabilitation 
functions while social care has care, rehabilitation and integration functions (Golinowska, 2010). The following units are distinguished in the health care system: (a) hospitals, (b) care and treatment facilities (c) nursing and care facilities (d) palliative care homes. Social care is provided by two types of social welfare homes: residential care homes and day care homes. Day care homes are for people who live with their family but the members are unable to provide care due to work activities. Residential care homes are institutions that provide 24-hour living conditions.

As WHO points out, accessibility to social and health services is currently one of the main problems of modern health care, therefore this topic should be included in scientific analyses and studies so that the results could be applied in practice (WHO's Global Health Estimates). Moreover, based on the research conducted by Blędowski et al. in 2012, it can be said that the existing assistance, both formal and informal, is insufficient for people with functional limitations.

The main objective of the research will be to map the needs for health and social services. The information presented in a graphical way with attributes will create a comprehensive and innovative knowledge base about the possibilities of developing personalized health and social services for people with special needs in a smart city.

\section{METHODOLOGY OF RESEARCH}

The research methods used in this paper include qualitative research with people with special needs and quantitative research based on data from the Central Statistical Office.

The purpose of the qualitative research was to conduct a diagnosis of the availability of primary health care and social services for people with special needs, and to identify directions for development to facilitate access for those in need. The study was conducted using an interview questionnaire among 11 people with special needs in 2021, during the COVID-19 pandemic. People participating in the study were identified by (a) age, (b) gender, (c) place of residence (large cities over 500,000, medium cities 100-500,000, small cities up to 100,000 , rural areas, (d) degree of disability (mild, moderate, severe), (e) type of disability (motor, visual, neurological, auditory, intellectual, respiratory and circulatory, metabolic, genitourinary, mental, obesity, rare/genetic diseases), (f) medical services, specialists the surveyed used (urologist, ophthalmologist, endocrinologist, neurologist, dentist, orthopedist, etc.). The specific aim of the research was to identify the needs and expectations of people with special needs, as well as to identify barriers to accessing health and social care.

The purpose of the quantitative research conducted using 2019 data from the GUS (Health and health care in 2019) was to identify institutional capacity to provide social and medical care to people with special needs. Statistical analysis was conducted on (a) the number of hospitals per 100,000 inhabitants in the province, (b) the number of hospital beds per 10,000 inhabitants in the province (c) the number of chronic medical care homes per 100,000 inhabitants in the 
province, (d) the number of beds in chronic medical care homes per 100,000 inhabitants in the province, (e) the number of nursing homes per 100,000 inhabitants in the province, (f) the number of beds in nursing homes per 100,000 inhabitants in the province.

After triangulation of qualitative and quantitative data (Figure 1), a map of health and social services needs was developed. Triangulation is the most well-known model of mixed-methods research, which involves collecting qualitative and quantitative data at the same time and comparing both sources in order to find out all kinds of differences, relationships and convergences between them (Musa and Nizamlsha, 2021).

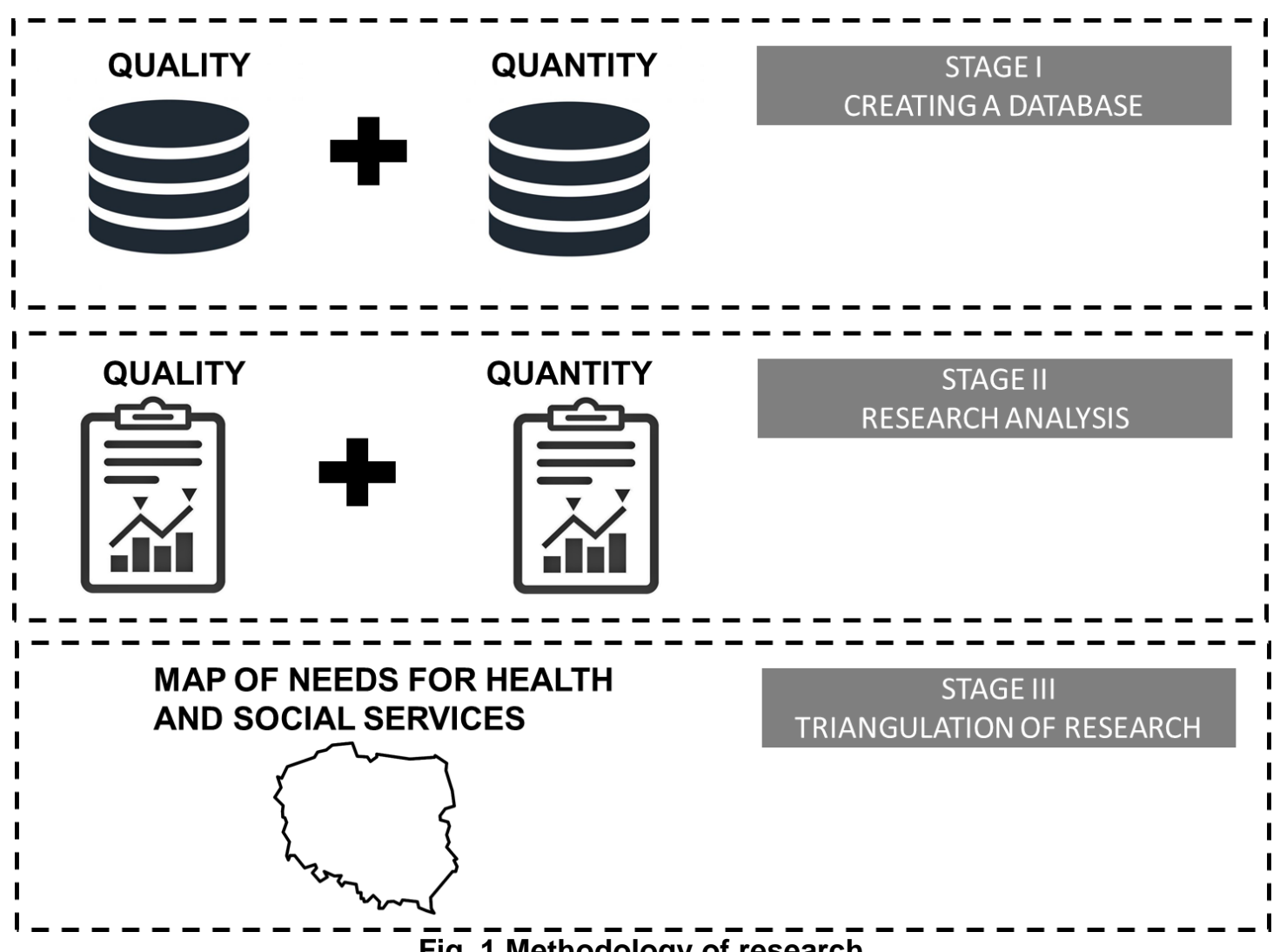

Fig. $\overline{1}$ Methōodology of research

It should be emphasized that the map of availability of health and social services is a tool for optimal rationalization of medical services. The data necessary to develop the spatial analysis should be obtained directly from patients, who are the simplest and cheapest tool to identify the availability of services and at the same time the health and social needs in local communities. Patients themselves are the source of knowledge about the lack of access to certain health and social services, especially the deficit ones, and about the problems they encounter while using the services. The map developed is a spatial analysis of the assessment of accessibility to health and social services in primary health care. The research results presented in this article are to present preliminary assumptions and to indicate further research fields in the presented problematic. 


\section{RESULTS}

In 2020, people with special needs faced many issues regarding the availability of health and social services due to the pandemic that was declared in March. The biggest problems that arose at the beginning of the pandemic were the lack of availability of information about the spread of the SARS-CoV-2 coronavirus for people who are deafblind and the lack of information about getting help if they get sick that people face when accessing health and social services. After conducting an interview questionnaire and a literature study, the following barriers to accessing health and social services were identified:

- Architectural barriers. Although more and more public buildings are being adapted or customized for people with special needs. The most common accommodations include landings, elevators, and restrooms adapted for people with mobility limitations. On the other hand, people with other types of disabilities may encounter architectural barriers, e.g. lack of communication paths for the blind, lack of voice announcements or Braille subtitles for the blind and visually impaired, inconsistent and unintuitive arrangement of rooms. In addition, there are times when entrances for people with COVID19 disabilities by people with functional limitations. After conducting an interview questionnaire among people with special needs, 6 types of barriers were distinguished, with mobility barriers are located at the side or back of the building, which causes discrimination and unequal treatment of patients. Figure 2 shows ready solutions for removing architectural barriers.
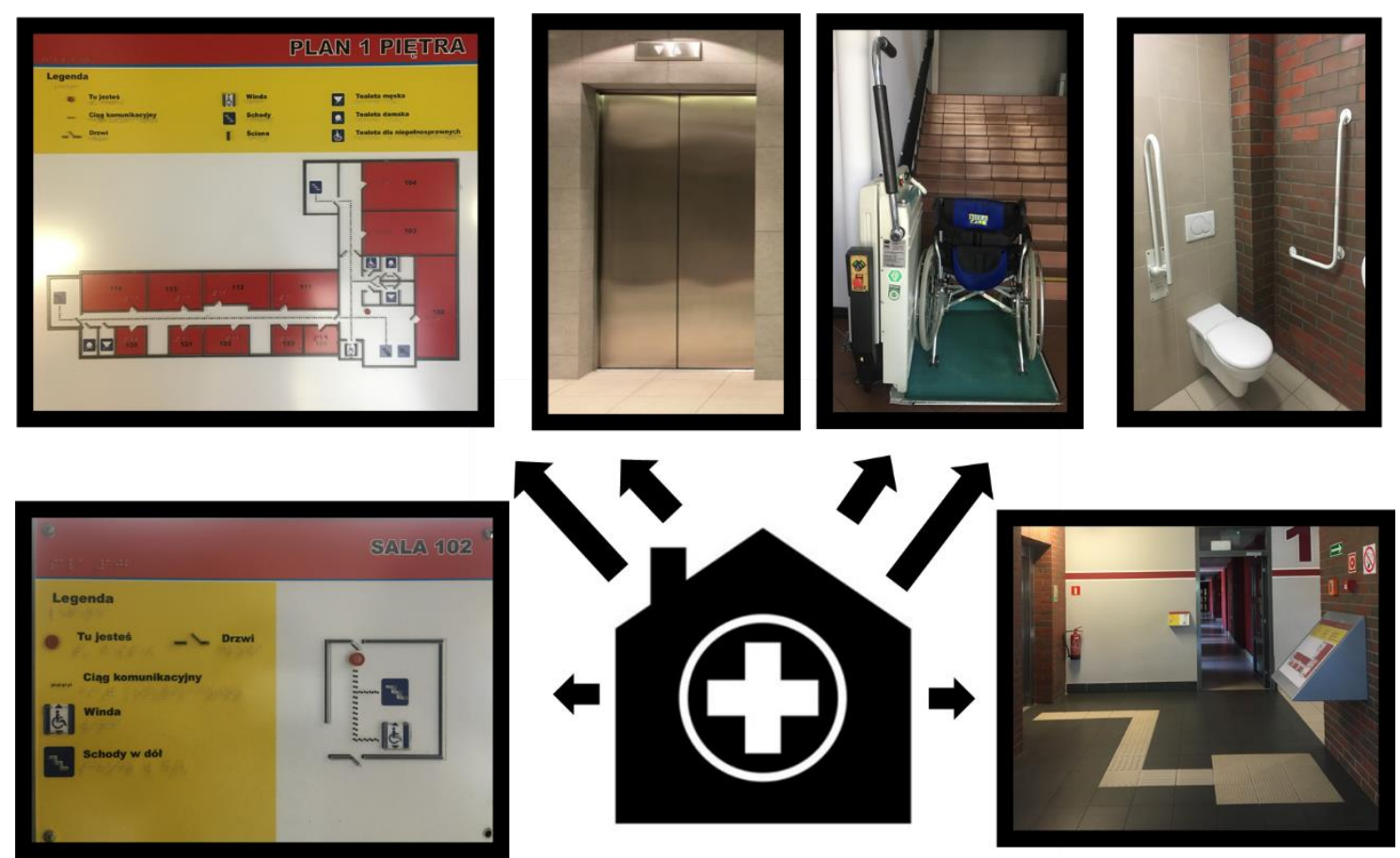

Fig. 2 Removing architectural barriers

- Infrastructure barriers. These barriers include inadequate equipment in hospitals, clinics, and nursing homes that makes it difficult or impossible to 
perform tests on patients with special needs. The most common infrastructure barriers include: inadequate bed, chair, couch, specialized equipment used for diagnostic tests.

- Information barriers. They are connected with the lack of information on a given topic or the lack of information in a form accessible for people with special needs. They concern inappropriate display of messages, announcements, room markings.

- Communication barriers. This is an inadequate exchange of information between medical personnel and the patient, which prevents free use of health and social services. The information provided by the medical personnel is incomprehensible to the recipient, as well as the information provided by the patient is incomprehensible to the medical personnel, for example, lack of knowledge of sign language.

- Mental barriers. This is an inappropriate approach to the patient because very often the medical staff does not address the patient, but rather the companion or assistant. Moreover, the attendant speaks on behalf of the patient. These barriers arise as a result of not wanting to seek a way to communicate with the patient and it puts the patient in an uncomfortable situation because they cannot make decisions on their own behalf.

- Competency Barriers. They occur when there is a lack of professional and soft competencies by the medical staff. Lack of professional competence is associated with lack of knowledge about the type of functional limitation, treatment modality, etc., while lack of soft competence is associated with tactless approach to the patient and inappropriate treatment.

In addition, one of the barriers to accessing health and social services is the long waiting times for medical consultations. Many times, the wait times for specialized tests are much longer for people with functional limitations due to the lack of appropriate equipment and facilities to perform the tests.

The second stage of the research involved statistical analysis of data from the Central Statistical Office (GUS) (2019), which aimed to identify institutional capacity to provide social and medical care to people with special needs. In Poland, at the end of 2019, there were 890 general hospitals with 166.8 thousand beds. The ratio of the number of hospitals per 10 thousand inhabitants was 0.23 and was the highest in the Śląskie (0.3), Opolskie (0.3) and Dolnośląskie (0.29) provinces and the lowest in the Wielkopolskie $(0.17)$, Pomorskie (0.19), Podkarpackie (0.19), Kujawsko-Pomorskie (0.19) and Świętokrzyskie (0.19) provinces. In 2019, the number of beds per 10,000 Polish citizens was 43.5 . More than $25 \%$ of all general hospital beds were located in the two largest provinces in terms of population: the Mazowieckie $(14.4 \%)$ and the Śląskie $(13.9 \%)$ provinces. The smallest provinces in terms of population, such as Lubuskie (2.4\%) and Opolskie (2.3\%), together accounted for $4.7 \%$ of general hospital beds in the country. Long-term care facilities play an important role in the country, providing patients with round-the-clock nursing, care and 
rehabilitation services, as well as the continuation of pharmacological and dietary treatment over a longer period of time due to the progressive aging process of the population. Long-term care is provided in nursing, assisted living, and hospice and palliative care facilities. In 2019, there were 371 chronic medical care homes, 162 nursing homes, and 154 inpatient hospice and palliative care facilities. The highest number of beds in chronic medical care and nursing care facilities per 10,000 population of provinces was in the provinces of Dolnoslaskie (10.7), Podkarpackie (10.11), Mazowieckie (9.38), and the lowest in the provinces of Wielkopolskie (2.39), Warmińsko-Mazurskie (4.09), Zachodniopomorskie (4.75). And inpatient social welfare facilities in 2019 were 1,837 with 118.9 thousand beds available. The average number of available beds in stationary social welfare institutions per 10 thousand inhabitants was 30.97. Table 1 and 2 present detailed data for 2019 by province in Poland.

Table 1 Availability of health and social services in the voivodships of Poland

\begin{tabular}{|c|c|c|c|c|c|c|c|c|c|c|c|c|}
\hline \multirow[b]{3}{*}{ Voivodships } & \multicolumn{4}{|c|}{ Hospitals } & \multicolumn{4}{|c|}{$\begin{array}{c}\text { Chronic medical } \\
\text { care homes }\end{array}$} & \multicolumn{4}{|c|}{ Nursing homes } \\
\hline & \multicolumn{2}{|c|}{ Facilities } & \multicolumn{2}{|c|}{ Bed } & \multicolumn{2}{|c|}{ Facilities } & \multicolumn{2}{|c|}{ Bed } & \multicolumn{2}{|c|}{ Facilities } & \multicolumn{2}{|c|}{ Bed } \\
\hline & $\begin{array}{l}\text { 정 } \\
\stackrel{0}{\circ}\end{array}$ & 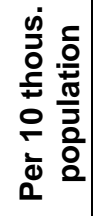 & $\begin{array}{l}\bar{\pi} \\
\text { 음 }\end{array}$ & 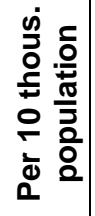 & $\begin{array}{l}\bar{\pi} \\
\stackrel{0}{0}\end{array}$ & 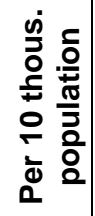 & $\begin{array}{l}\bar{\pi} \\
\text { 음 }\end{array}$ & 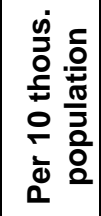 & $\begin{array}{l}\bar{\pi} \\
\stackrel{0}{0}\end{array}$ & 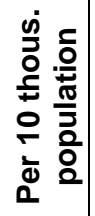 & $\begin{array}{l}\text { तू } \\
\text { 음 }\end{array}$ & 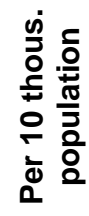 \\
\hline Dolnośla & 84 & 9 & 13152 & 45,3 & 46 & 16 & 2288 & 7,89 & 19 &, 07 & 840 & 2,90 \\
\hline $\mathrm{Ku}$ & 40 & 0,19 & 8867 & 42,8 & 23 & 0,11 & 1050 & 5,07 & 11 & 0,05 & 458 & 2,21 \\
\hline Lubelskie & 46 & , ¿८ & 9984 & 47,4 & 17 &, 08 & 871 & 4,13 & 7 &, 03 & 289 & 1,37 \\
\hline Lubuskie & 24 & 0,24 & 3978 & 39,3 & 10 & 0,10 & 453 & 4,48 & 1 & 0,01 & 56 & 0,55 \\
\hline Łódzkie & 63 & 0,26 & 11516 & 46,9 & 26 & 11 & 1656 & 6,75 & 13 & 05 & 408 & 1,66 \\
\hline Małopols & 73 & 0,21 & 13750 & 40,3 & 38 & 0,11 & 3023 & 8,86 & 3 & 0,01 & 110 & 0,32 \\
\hline Mazowieckie & 112 & 0,21 & 24028 & 44,3 & 45 & 0,08 & 3784 & 6,98 & 23 &, 04 & $\begin{array}{c}130 \\
5\end{array}$ & 2,41 \\
\hline Opolskie & 29 & 0,30 & 3839 & 39,1 & 17 & 0,17 & 866 & 8,81 & 3 & 0,03 & 33 & 0,34 \\
\hline Podkarp & 41 & 010 & 9349 & 44,0 & 25 & 0,12 & 1431 & 6,73 & 15 & 0,07 & 720 & 3,38 \\
\hline Podlaskie & 32 & 0,27 & 5086 & 43,2 & 10 & 0,08 & 291 & 2,47 & 10 & 0,08 & 453 & 3,84 \\
\hline Pomorskie & 44 & 0,19 & 8433 & 36,0 & 21 & 0,09 & 971 & 4,14 & 5 & 0,02 & 200 & 0,85 \\
\hline Śląskie & 136 & 0,30 & 23287 & 51,5 & 41 & 0,09 & 2527 & 5,59 & 24 & 0,05 & $\begin{array}{c}144 \\
3\end{array}$ & 3,19 \\
\hline Świetokrzyskie & 24 & 0,19 & 5348 & 43,3 & 15 & 0,12 & 840 & 6,81 & 3 & 0,02 & 74 & 0,60 \\
\hline $\begin{array}{l}\text { Warmińsko- } \\
\text { mazurskie }\end{array}$ & 39 & 0,27 & 6241 & 43,9 & 12 & 0,08 & 357 & 2,51 & 5 & 0,04 & 225 & 1,58 \\
\hline Wielkopolskie & 59 & 17 & 13094 & 37,4 & 16 & 0,05 & 493 & 1,41 & 10 & 0,03 & 343 & 0,98 \\
\hline $\begin{array}{l}\text { Zachodnio- } \\
\text { pomorskie }\end{array}$ & 44 & 0,26 & 6876 & 40,5 & 9 & 0,05 & 422 & 2,49 & 10 & 0,06 & 385 & 2,27 \\
\hline
\end{tabular}

Source: Own study based on data from the Central Statistical Office, 2019 (https://stat.gov.pl/) 
Table 2 Availability of health and social services in the voivodships of Poland

\begin{tabular}{|c|c|c|c|c|c|c|c|c|}
\hline \multirow[b]{3}{*}{ Voivodships } & \multicolumn{4}{|c|}{ Palliative care wards and hospices } & \multicolumn{4}{|c|}{ Stationary social welfare facilities } \\
\hline & \multicolumn{2}{|c|}{ Facilities } & \multicolumn{2}{|c|}{ Bed } & \multicolumn{2}{|c|}{ Facilities } & \multicolumn{2}{|c|}{ Bed } \\
\hline & ॠٓ & 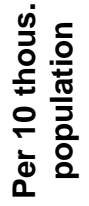 & 횸 & 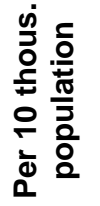 & 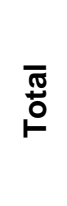 & 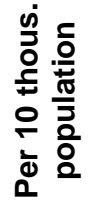 & 䙲 & 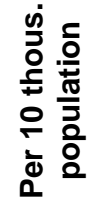 \\
\hline Dolnośląskie & 15 & 0,05 & 322 & 1,11 & 119 & 0,41 & 8447 & 29,12 \\
\hline $\begin{array}{l}\text { Kujawsko- } \\
\text { pomorskie }\end{array}$ & 9 & 0,04 & 164 & 0,79 & 87 & 0,41 & 5828 & 28,12 \\
\hline Lubelskie & 11 & 0,05 & 159 & 0,75 & 83 & 0,39 & 5729 & 27,17 \\
\hline Lubuskie & 5 & 0,05 & 75 & 0,74 & 47 & 0,46 & 2933 & 28,99 \\
\hline Łódzkie & 4 & 0,02 & 66 & 0,27 & 111 & 0,45 & 8109 & 33,03 \\
\hline Małopolskie & 12 & 0,04 & 311 & 0,91 & 166 & 0,48 & 10785 & 31,61 \\
\hline Mazowieckie & 15 & 0,03 & 320 & 0,59 & 288 & 0,53 & 17593 & 32,44 \\
\hline Opolskie & 6 & 0,06 & 91 & 0,93 & 61 & 0,62 & 4262 & 43,37 \\
\hline Podkarpackie & 14 & 0,07 & 302 & 1,42 & 84 & 0,39 & 5975 & 28,08 \\
\hline Podlaskie & 4 & 0,03 & 54 & 0,46 & 57 & 0,48 & 3518 & 29,85 \\
\hline Pomorskie & 13 & 0,06 & 229 & 0,98 & 118 & 0,50 & 7580 & 32,33 \\
\hline Śląskie & 14 & 0,03 & 276 & 0,61 & 229 & 0,50 & 13792 & 30,52 \\
\hline Świętokrzyskie & 16 & 0,13 & 294 & 2,38 & 70 & 0,56 & 4380 & 35,49 \\
\hline $\begin{array}{l}\text { Warmińsko- } \\
\text { mazurskie }\end{array}$ & 3 & 0,02 & 61 & 0,43 & 90 & 0,63 & 5258 & 36,95 \\
\hline Wielkopolskie & 7 & 0,02 & 109 & 0,31 & 149 & 0,42 & 9102 & 26,01 \\
\hline $\begin{array}{l}\text { Zachodnio- } \\
\text { pomorskie }\end{array}$ & 6 & 0,04 & 124 & 0,73 & 78 & 0,45 & 5586 & 32,93 \\
\hline
\end{tabular}

Source: Own study based on data from the Central Statistical Office, 2019 (https://stat.gov.pl/)

In the next step, the availability of individual health and social services was assessed for the provinces. A point scale was used $(1-$ services at the lowest level, 16 - services at the highest level) and then identified provinces that are best suited for people with functional limitations. Table 3 presents the scoring analysis along with the final score.

The organization of accessibility to health and social services is currently a major challenge facing researchers and health care decision makers. The results of the research will allow rational planning of investments by the administrators of public funds in health care. Decisions on the allocation of investment resources for health care should be based on maps of availability of health and social services, which take into account the health needs of the population. Maps of health needs can be an effective tool if they are applied according to an accepted procedure and accepted in practice by all stakeholders of the system, and not based on what services providers are willing to provide. 
Table 3 Point analysis of the availability of health and social services

\begin{tabular}{|c|c|c|c|c|c|c|c|c|c|c|c|}
\hline \multirow{3}{*}{ Voivodships } & \multicolumn{11}{|c|}{ Scoring in relation to 10 thous. population } \\
\hline & \multicolumn{2}{|c|}{ Hospitals } & \multicolumn{2}{|c|}{$\begin{array}{l}\text { Chronic } \\
\text { medical } \\
\text { care } \\
\text { homes }\end{array}$} & \multicolumn{2}{|c|}{$\begin{array}{l}\text { Nursing } \\
\text { homes }\end{array}$} & \multicolumn{2}{|c|}{$\begin{array}{l}\text { Palliative } \\
\text { care } \\
\text { wards and } \\
\text { hospices }\end{array}$} & \multicolumn{2}{|c|}{$\begin{array}{l}\text { Stationary } \\
\text { social welfare } \\
\text { facilities }\end{array}$} & \multirow{2}{*}{$\begin{array}{l}\text { Total } \\
\text { points }\end{array}$} \\
\hline & 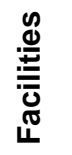 & @̊n & 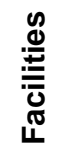 & ஜू & 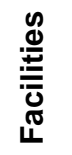 & 号 & 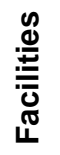 & 里 & 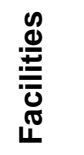 & @̊ & \\
\hline Dolnośląskie & 3 & 13 & 15 & 14 & 14 & 13 & 10 & 14 & 3 & 6 & 105 \\
\hline $\begin{array}{l}\text { Kujawsko- } \\
\text { pomorskie }\end{array}$ & 4 & 7 & 10 & 8 & 10 & 10 & 7 & 10 & 4 & 4 & 74 \\
\hline Lubelskie & 1 & 15 & 3 & 5 & 5 & 7 & 10 & 9 & 1 & 2 & 58 \\
\hline Lubuskie & 8 & 4 & 9 & 7 & 1 & 3 & 10 & 8 & 7 & 5 & 62 \\
\hline Łódzkie & 6 & 14 & 10 & 11 & 10 & 9 & 1 & 1 & 6 & 13 & 81 \\
\hline Małopolskie & 10 & 5 & 10 & 16 & 1 & 1 & 7 & 11 & 10 & 9 & 80 \\
\hline Mazowieckie & 13 & 12 & 3 & 13 & 8 & 12 & 4 & 5 & 13 & 11 & 94 \\
\hline Opolskie & 15 & 3 & 16 & 15 & 5 & 2 & 13 & 12 & 15 & 16 & 112 \\
\hline Podkarpackie & 2 & 11 & 13 & 10 & 14 & 15 & 15 & 15 & 1 & 3 & 99 \\
\hline Podlaskie & 9 & 8 & 3 & 2 & 16 & 16 & 4 & 4 & 9 & 7 & 78 \\
\hline Pomorskie & 11 & 1 & 7 & 6 & 3 & 5 & 13 & 13 & 11 & 10 & 80 \\
\hline Śląskie & 12 & 16 & 7 & 9 & 10 & 14 & 4 & 6 & 12 & 8 & 98 \\
\hline Świętokrzyskie & 14 & 9 & 13 & 12 & 3 & 4 & 16 & 16 & 14 & 14 & 115 \\
\hline $\begin{array}{l}\text { Warmińsko- } \\
\text { mazurskie }\end{array}$ & 16 & 10 & 3 & 4 & 8 & 8 & 1 & 3 & 16 & 15 & 84 \\
\hline Wielkopolskie & 5 & 2 & 1 & 1 & 5 & 6 & 1 & 2 & 5 & 1 & 29 \\
\hline $\begin{array}{l}\text { Zachodnio- } \\
\text { pomorskie }\end{array}$ & 7 & 6 & 1 & 3 & 13 & 11 & 7 & 7 & 7 & 12 & 74 \\
\hline
\end{tabular}

Source: Own study

\section{DISCUSSION}

Based on the survey, a map of needs for health and social services was developed (Figure 3). The darker the color on the map, the worse the access to social and health services. The Wielkopolskie Voivodeship received the lowest assessment in terms of access to health and social services, while the Dolnośląskie, Opolskie and Świętokrzyskie Voivodeships received the highest assessment. The availability of social and health services in Poland is not well developed and, moreover, it is not evenly distributed, which causes unequal treatment of Poles. It is worth noting that voivodships with the highest population do not have the best developed availability of social and health services.

Ensuring the availability of health and social services is the responsibility of each member country of the European Union, so the rationalization of health and social services is a task with which the states must face. The presented accessibility map is a proposal from the scientific and practical point of view to optimize the management processes of health care units. The issues of equitable distribution and access to medical services are compounded by economic and political conditions. Lack of access to health and social services as well as the difficult experience of patients with medical appointments and the 
inadequacy of the offices to meet their needs result in discouragement to use services, which has a negative impact on health status.

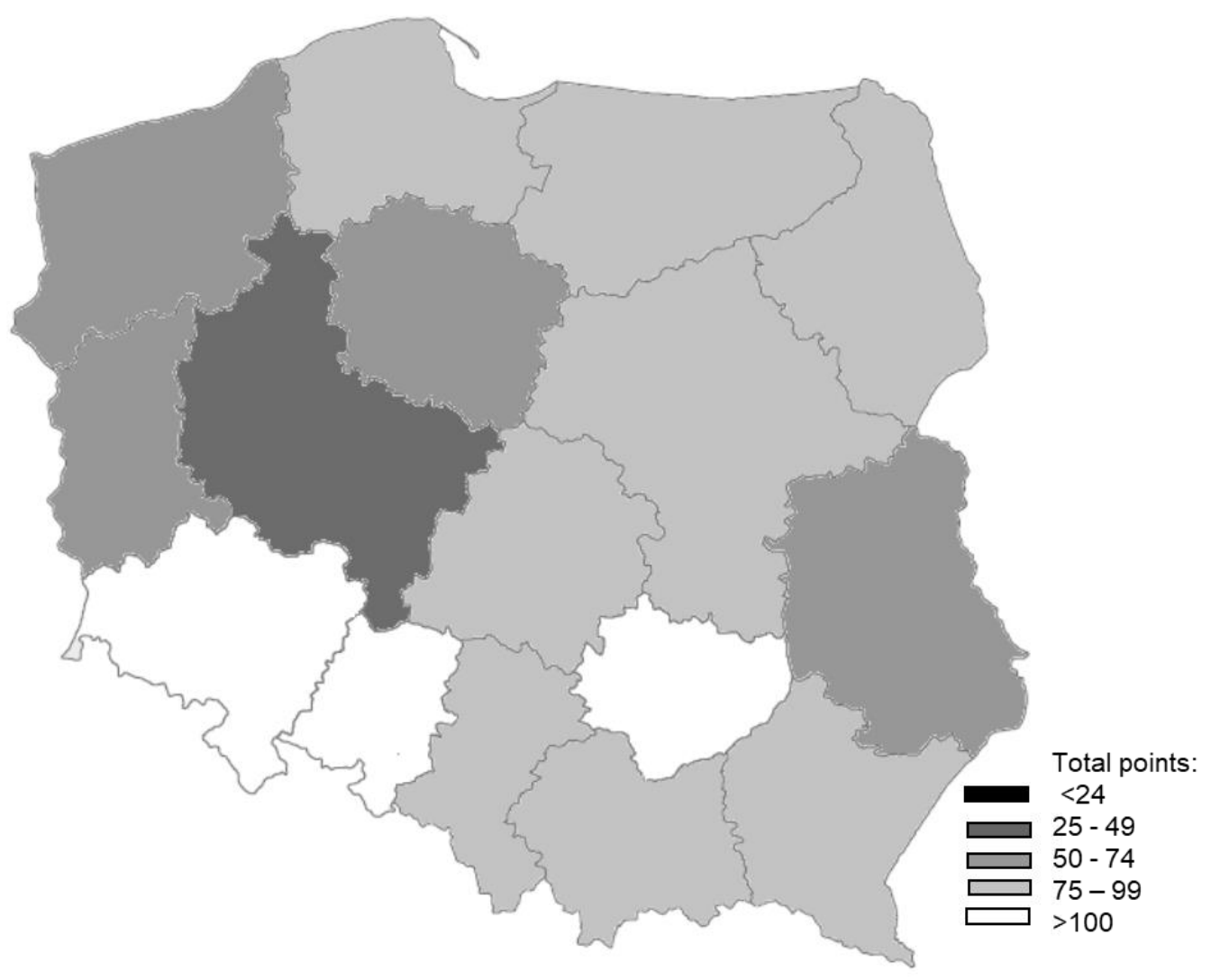

Fig. 3 Map of needs for health and social services

\section{CONCLUSION}

Issues of equitable distribution and access to medical services are compounded by economic and political considerations (Kanownik, 2017). A key challenge to the smooth functioning of the health care system is the need to identify and address health and social needs when developing an accessibility map. In order to bridge the gap in accessibility to health and social services, it is necessary to continuously analyze health needs in the population.

An important aspect is to adapt health care units to people with functional limitations, removing architectural and infrastructural barriers. In addition, patients with dysfunctions are very often treated by medical staff - doctors, nurses, registration staff - in a discriminatory way, because they are not treated seriously, as a full-fledged patient, but as a childish patient who cannot make decisions about his treatment on his own. Moreover, the lack of communication in a way that is accessible to people with functional limitations is also discriminatory. The information provided by the staff is often incomprehensible to patients because of its form.

On the basis of the spatial analysis carried out, the availability of social and health services in Poland is not well developed and, moreover, it is not evenly distributed, which results in unequal treatment of Poles. 


\section{ACKNOWLEDGEMENTS}

The article is the result of research conducted at the Faculty of Production Engineering, Department of Organization and Management, Silesian University of Technology within the framework of the statutory work entitled "Identification of opportunities for the development of personalized health services for people with special needs." (No. 13/030/BKM_21/0068).

\section{REFERENCES}

Błędowski, P., Szatur-Jaworska, B., Szweda-Lewandowska, Z. and Kubicki, P. (2012). Raport na temat sytuacji osób starszych w Polsce, Instytut Pracy i Spraw Socjalnych. Available at: http://senior.gov.pl/source/raport_osoby\%20starsze.pdf [Accessed 8 Jun. 2021].

Derejczyk, J., Bień, B., Kokoszka-Paszkot, J. and Szczygieł J. (2016). Gerontology and geriatrics in Poland against Europe - is it necessary to invest in?. Zdrowie Publiczne i Zarządzanie 14 (1), pp. 101-109.

Golinowska, S. (2010). The LTC System for the Elderly in Poland. ENEPRI-ANCIEN Research Report 83. Available at: https://www.files.ethz.ch/isn/122415/Poland.pdf [Accessed 10 Jun. 2021].

Kanownik, G. (2017). Bezpieczeństwo pacjenta a dostępność do usług zdrowotnych. Finanse, Rynki Finansowe, Ubezpieczenia, 1 (85), pp. 621-632.

Kaźmierczak, J., Bartnicka, J., Borgosz, G., Ikem, B., Jurasik, J., Kręt, P., Pietrulińska, N. and Radomski M. (2020). Developing the cognitive abilities of elderly people with the use of IT technologies: presentation of the project assumptions and description of the research concept. [in:] Multidisciplinary Aspects of Production Engineering, MAPE 2020. Engineering and Technology, Ed. Jacek Sitko. Warszawa: SCIENDO, pp. 505-516.

Levesque, J.F., Harris, M.F and Russell, G. (2013). Patient-centred access to health care: Conceptualising access at the interface of health systems and populations. International Journal for Equity in Health, 12 (18).

Marchetti, D., Oliveira, R. and Figueira, A. R. (2019). Are global north smart city models capable to assess Latin American cities? A model and indicators for a new context. Cities, 92 (2019), pp. 197-207.

Meyer, S.B, Luon, T.C.N., Mamerow, L. and Ward, P.R. (2013). Inequities in access to healthcare: Analysis of national survey data across six Asia-Pacific countries. BMC Health Services Research, 13 (238).

Musa, M., Nizamlsha, A.S. (2021). Holistic view of safety culture in aircraft ground handling: Integrating qualitative and quantitative methods with data triangulation. Journal of Air Transport Management, 92 (C).

Sowa, A. (2016). Usługi zdrowotne i socjalne wobec populacji starszej, przewlekle chorej i niepełnosprawnej realizowane w pomocy społecznej. Podstawy regulacyjne i praktyka. Zdrowie Publiczne i Zarządzanie, 14 (1), pp. 63-72.

Sowa, A. and Beaumont, K. (2015). Good Practices and Policies Fostering Social Engagement of Older People with Health Limitations. The Case of Poland, MoPAct Research Report, Centrum Analiz Społeczno-Ekonomicznych CASE.

WHO's Global Health Estimates. Available at: https://www.who.int/ [Accessed 10 Jun. 2021]. 
World

Urbanization

Prospects,

(2014).

Available

at: https://population.un.org/wup/publications/files/wup2014-highlights.pdf [Accessed 8 Jun. 2021].

Abstract: The health care system should offer and provide a variety of services without undue delay. Due to numerous technical, financial and human resource constraints, not all services can be offered both without restrictions and in equal measure in places of different sizes of residence. As a result of qualitative and quantitative research, a map of accessibility to social and health services was drawn up, taking into consideration the division of the country into voivodeships with different population. Spatial analysis showed great diversity in terms of service availability. Voivodships with the highest accessibility of health and social services are Dolnośląskie, Opolskie and Świętokrzyskie, while the worst situation is in Wielkopolskie. Moreover, the article identifies the main problems that people with limited functionality encounter when using health and social services.

Keywords: sustainable development, health services, social services, spatial analysis, people with special needs 